\title{
Poster
}

\section{THE LONG TERM EFFECTS OF DIFFERENT TRAINING MODELS ON POWER, SPEED, ABILITY AND ANAEROBIC CAPACITY OF 13-16 YEARS OLD FEMALE BASKET BALL PLAYERS}

Gürkan Yilmaz, ${ }^{1}$ Rüçhan İri, ${ }^{1}$ M Serdar Çözelii ${ }^{1}$ Niğde Üniversitesi Beden Eğitimi ve Spor Yüksek Okulu, Niğde, Turkey; ${ }^{2}$ Çaybașı Atatürk İlköğretim Okulu, Çaybașı, ORDU, Turkey

\subsection{6/bjsm.2010.078725.84}

The aim of this study is to investigate the 16 -week different training models in terms of power, speed, ability and aerobic capacity in 13-16 years old female basketball players. 20 female basketball players are divided into two groups as 'power endurance' and 'general endurance'. Different 90 -min training models are applied to both groups 3 days a week throughout 16 weeks. The 1st group (power endurance - $\mathrm{PE}$ ) is applied interval training method and the 2nd (general endurance-GE) group is applied permanent runs method. The groups in the study are applied 20-m speed run, squat jump, countermovement jump and running-based aerobic speed run before and after the exercises. Paired-samples $t$ test is done for arithmetical mean, SD and the evaluation between groups, and non-parametric test. Mann-Whitney $U$ test is done for the comparison of the two groups. A significant difference is found in the assessment of EÖ and ES, grouped shuttle test in PE group and the 5th run of 
the 35-m running test while there is no significant difference ( $p>0.005)$ in the other values. In the GE group, a significant difference in favour of ES is seen in valid shoot test, 2nd run, 5 th run and 6 th run. In the evaluation of the groups, significant differences have been found in favour of shoots after exercise, grouped shuttle test, valid shoot test, run tests, 1st and 2nd run tests before and after exercise, and ES PE after 3rd, 4th, 5 th and 6 th runs. In conclusion, initial power and speed values have been kept in both training models. Aerobic capacity and ability have increased in PE groups. Thus, it can be suggested that the application of interval training method besides cardiovascular and metabolic specific factors in the improvement of endurance in children may be useful. 